\title{
Inter-organizational Public e-Service Development: Emerging Lessons from an Inside-Out Perspective
}

\author{
Marie-Therese Christiansson, Karin Axelsson and Ulf Melin
}

\section{Linköping University Post Print}

\section{Tweet}

N.B.: When citing this work, cite the original article.

Original Publication:

Marie-Therese Christiansson, Karin Axelsson and Ulf Melin, Inter-organizational Public eService Development: Emerging Lessons from an Inside-Out Perspective, 2015, ELECTRONIC GOVERNMENT (EGOV 2015), 183-196.

http://dx.doi.org/10.1007/978-3-319-22479-4_14

Copyright: The Authors.

Preprint ahead of publication available at: Linköping University Electronic Press http://urn.kb.se/resolve?urn=urn:nbn:se:liu:diva-122226 


\title{
Inter-organizational Public E-service Development: Emerging Lessons from an Inside-Out Perspective
}

\author{
Marie-Therese Christiansson ${ }^{1}$, Karin Axelsson ${ }^{2}$, Ulf Melin ${ }^{2}$ \\ ${ }^{1}$ Department of Information Systems, Karlstad University, Karlstad, Sweden \\ marie-therese.christiansson@kau.se \\ ${ }^{2}$ Department of Management and Engineering, Information Systems, Linköping \\ University, Linköping, Sweden \\ \{karin.axelsson, ulf.melin\}@liu.se
}

\begin{abstract}
E-service development has grown to become a daily practice in most public organizations as a means for realizing digital agendas and e-government initiatives on different levels (local, regional, national and transnational governmental levels). Public e-service development is often an inter-organizational (IO) effort with multiple actors and organizations involved in the multi-faceted dimensions of design, development and delivery decisions. Still, there is a lack of research focusing on IO public e-service development practices in particular. In order to address this lack we elaborate on reported challenges and their implications for IO public e-service development in practice. By returning to two empirical cases of IO public e-service development, the IO dimension is evolved. Our purpose is to highlight challenges in IO public e-service development with implications for research and practice. Findings are presented as eight emerging lessons learned from an inside-out perspective related to phases in IO public e-service development processes.
\end{abstract}

Keywords. Public e-service, Inter-organizational, IO e-service development, IO dimension, Government, IS development

\section{Introduction}

Many initiatives and efforts in the public sector are aiming to foster citizen engagement and provide useful and meaningful e-services to citizens and businesses. Previous studies have reported on challenges (barriers and shortcomings) in terms of participation, such as low sustainability, poor citizen acceptance, coordination difficulties, lack of understanding, and failure to assess impact (e.g. [35]). Reported challenges and critical success factors of e-government adoption by Rana et al. [34], are highlighting that technological barriers, lack of security and privacy, lack of trust, lack of resources, a digital divide, poor management and infrastructure, lack of awareness, legal barriers, lack of IT infrastructure, and resilience were among some of the most commonly experienced aspects. Corresponding factors for the success of egovernment initiatives were citizens' satisfaction, information accuracy, security, and 
privacy. Hence, several issues are identified in relation to what should be taken into consideration, managed and achieved in e-government. Nevertheless, there is not much published in the past years of research regarding challenges in interorganizational (IO) e-service development processes. Recent studies are not focusing on the development process per se, but on concepts that can be useful when designing projects [15], collaboration competency and partner match [40] and questions the initiator needs to answer in advance [39].

In Sweden the government's strategy for a digital collaborative public administration [13], like in many other countries, is a driver. The strategy is a demand for agencies to increase their ability to collaborate across organizational borders as well as across geographical, legal, functional, technical, operational, and cultural boundaries, and a part of the realization of the national digital agenda [14]. Objectives behind strategies for e-government are many and expressed on different governmental levels. In Sweden, - the primary empirical domain in this paper - these are the national, regional and local levels together with the European level [12]. Hence, the daily practice, regardless of national differences, of public e-service development has many stakeholders and involves private, public and non-profit actors working to realize multiple digital strategies and agendas. Chun et al. [8] discuss forces in public collaboration in terms of citizen-, value-, economic/cost- and technology-driven projects. Thus, IO e-service development should respond to one or multiple drivers in each partaking organization. In addition, the IO development process involves actors from different sectors and roles on different levels with different objectives.

The purpose of this paper is to further elaborate on the understanding of challenges in IO public e-service development processes with the aim of generating lessons for such development. Our approach is to explore research on challenges in e-government and IO collaboration onto IO public e-service development practice. In addition, critical success factors identified by research are not always to be found in practice [9]. For that reason, we revisit the development practice in two IO public e-service development cases, to achieve summative reflections on IO challenges, justifying and validating findings of lessons learned.

Qualitative and interpretive case studies (one regional and one national case) are used (cf. [23], [41], [42] and the study is classified as retrospective with a reflective follow-up on incentives, objectives, and performance. Incentives and objectives behind e-services are emphasized in our lessons learned (constrains and affordances [11]) in order to discuss impacts on development issues. Our role in the cases ranged from "insiders" as action researchers (e.g. [38]) to "outsiders" as more critical and reflective researchers [31]. Based on that we use the concept of an inside-out perspective, defined as the (IO) developing practice involving stakeholders in providing, and delivering a public e-service. Hence, the work practice performed by multiple stakeholders to identify pre-conditions, analyzing business processes and systems requirements, development, tests and maintenance issues. We use the inside-out perspective as a vehicle to analyze the roles and actors partaking in the design of an e-service and the delivery in terms of providing and using it. In reverse, an outside-in perspective can be viewed as a user receiving value from the e-service provision. Besides empirical sources such as semi-structured interviews, informal conversations, internal and 
external documents, project meetings and seminars, business process models, user tests of a web portal prototype and e-services under development were also used in data collection. The empirical data generation was guided from IO challenges identified in our literature review. In order to search for literature with an explicit IO focus (in purpose, research design and findings), we used terms such as "challenges" (barriers/success), "inter-organizational", "public e-service", "collaborative e-government initiatives", and "multiple organizations" when searching in Scopus, ScienceDirect and Google Schoolar. Madsen et al. [25] confirms our limited hits of publications, as only one paper out of 50 in their study addressed the developing practice.

Studies reported on e-service challenges and success in e-government are not focusing on the IO dimension [2], [34], [19] in the end-to-end development process [33], [40], [39], [15]. In order to learn from challenges in the development work practice, two IO public e-service development case studies are revisited. The analysis was performed based on phases in the development process and IO dimensions to achieve summative reflections in lessons.

In the following the paper is outlined as follows: First we discuss challenges and successes in IO public e-service development. Our inductively generated lessons are then discussed in relation to the IO dimension identified in previous research. In the concluding section, we summarize our conclusions with implications for practice and research, limitations and suggestions on future research.

\section{IO Public e-Service Development}

Governments are constantly in a state of change and adjustments, in relation to their environments, i.e. political, social, economic and cultural settings [9]. Political directives with the objective of increasing service and grade of transparency and effectiveness drive continuous improvement at the level of public administration. Multiple channels for digital contact, communication and interaction are used in order to provide and meet overall goals and agendas for digitalization. Messages from the EU level concern efforts to improve citizens' interactions, provide more efficient and effective administrations, and increase the transparency of government to enhance a more democratic society [44]. Public e-services are essential in governmental use of digital channels. Providing information systems with online services based on automated end-to-end processes or to some extent replacing manual case handling. Hence, public e-services are services for both external and internal use in a governmental and political setting [23]. The complexities and challenges of IO public e-service development are discussed below in terms of pre-conditions, design, and development and delivery phases in the process.

\subsection{Pre-conditions for e-Service Development}

Resource allocations, the future-readiness of innovations, and influences from institutional and environmental issues have been identified as crucial for incentives and goals in public e-service development [9]. In addition, Iskender and Özkan [19] relate 
identified success factors to net benefits in terms of cost savings, expanded communication channels to users, expanded service portfolio, increased information retrieval, and time savings. Moreover, their research reports on systems quality (adaptability, availability, reliability, response time, and usability), information quality (completeness, ease of understanding, personalization, relevance and security), service quality (assurance, empathy and responsiveness), use (nature of use, navigation patterns, number of site visits and transactions), and user satisfaction (repeat use, visits and experiences). To identify possible projects should be the first activity (c.f. [18]).

If we analyze the IO dimension of e-service development more closely, actors in IO development processes in general assume a responsibility of their own for results and also express a need and a willingness to collaborate through personal investments, commitments, and a joint use of resources in a win-win relationship [1], [4]. The latter might briefly be described as the work practices where activities are performed by the organizations with the best capability to provide the resources (e.g. competence, time, technology, and information) and performance required in delivery. Stakeholders might differ in their possibilities to collaborate and in their expectations of outcomes. Nonetheless, initiatives and decisions could be explained as driven by several rationales [5]. The most common is cost reduction; others include the possibility to gain access to adequate and competent resources, and to improve business process performance [1]. Hence, these rationales clearly match e-government goals to improve citizen interaction to make the administration more efficient and effective, and to increase transparency.

In the forecasting phase, the factors to consider in order to avoid failures are: the organization's behavior in relation to service innovation, idea generation sources and actions as well as organizational structure and resource allocation impact, that is internal and external value [2]. The IO public environment is related to the many involved stakeholders; for instance private, public and non-profit actors involved in the design, development and delivery of e-services [9]. The degree of in-house versus external resources varies and might include vendors and suppliers [4] acting together. Organizations collaborate in order to facilitate and perform actions across such boundaries, as well as the boundaries between sectors when private parties take the roles traditionally performed by government organizations [21]. Those involved are stakeholders in e-service design, development and delivery, actors affecting the development, and actors affected by the result [22]. Guha and Chakrabarti [15] argue for a better understanding of issues such as the politics of partner selection, the achievement of network goals, institutionalization processes, network structuring, and incentive design. Tsou's [40] findings show that collaboration competency and partner match relate positively to knowledge integration, which in turn relates positively to eservice innovation. Organizational compatibility and a prior history of business relations are critical elements of partner match. Furthermore, the study indicates the importance of similar management styles and cultures (ibid.). The underlying theme is that the public sector requires closer working relationships between government stakeholders [16:539]; "The development of meaningful and effective relationships between central government, individual government agencies and users of public eservice are critical to the success of e-service". 


\subsection{Design and Development of e-Services}

E-service development can be viewed as the digitalization of business processes to design and develop information systems (IS) with a front-end interface towards the user and back-end business logics, systems and channels. Tasks and issues identified as important for success are defining the scope, staffing, setting of realistic deadlines, reconstruction of processes, requirements, technologies, usability tests, anchoring of solution, hosting, maintaining, training, and problem management [3], [27], [2], [40], [34]. Thus, appropriate skills for the design and development of e-services range from project management, analysis and design, development, integration, tests and to systems maintenance. In addition, Iskender and Özkan [19] relate their findings on success factors (the inverse side of reported challenges) in e-government to the technical base (compatibility, accessibility, standards, interoperability, integrity, maintainability, ease of use), the social base (awareness, intention and education among stakeholders, digital divide and riskless environment), the organizational dimension (visionary leaders, accountability, organizational transformation plans, management support, institutional support and culture, IT investment, transparency and citizen centric) as well as the political and the legal base (political support, macro transformation plans and consistent regulatory framework). Political decisions need to be implemented in development and politicians need to be convinced of the necessity of investing in enabling technology, as well as to ensure the individual and political rights and obligations of citizenship. The public dimension, on the other hand, means to ensure access to services for all citizens, in all channels, to provide diversity, accessibility and usability [22]. Hence, the political, public and personal character of eservices (e.g. My Pages) might be a driver or a barrier in e-service development.

A number of factors have been identified as important in IO public e-service development, such as collaboration and partner match, complex or straight-forward development process, appropriate in-house/in-team skills, the coordination of parallel projects, laws and regulations for interdependencies/data interchange/definitions/ structure, infrastructure and resilience [3], [27], [40], [15]. In addition, transformation of strategies into the right policy measures and practical actions is crucial [33].

Strategic business and IT alignment, in the context of e-service development, is a multi-level task and a complex challenge which involves many concerns [10]. Angelopoulos et al. [2:103] indicate that “... success or failure is not the result of managing one or two activities very well; rather it is the result of a holistic approach, managing several aspects competently and in a balanced manner". Managing e-service development includes striving for alignment, not only with the political, business and individual levels (i.e. the social and intellectual dimensions). The (IO) collaboration in terms of the political, business and individual levels of each participating organization, as well as the general domain must also be considered. Moreover, e-service development might be conducted in transnational, national, regional and local government levels, at the same time. With a decision of 25 new e-services on one level (in a transnational project) and the development and implementation of the same e-services on another level (the local), problems occur if the mandate to demand the required resources for implementation is lacking [26]. Decisions about e-services might be 
driven by internal needs and the opportunity-driven "build it and they will come" strategy [20] or, on the other hand, be made on the basis of demand-driven development putting the external target group in focus with its needs and behavior [43]. The strategy adopted by Swedish agencies working with e-government [37:86] states: "The development of e-services should be based on individuals and business needs". However, support for performing user-driven e-service development is still in its infancy. Aiming for IT (e.g. e-services) to be aligned with business and striving for a mutual alignment of business and IT are two different perspectives [24]. IT should not only be regarded as a support function for the organization. Instead, IT can both enable and drive change depending on the situation (ibid.). Another perspective concerns the alignment on non-strategic levels. Alignment between strategies is important in order to achieve successful organizations; in addition the intellectual and social dimension of alignment is crucial to address. It includes aspects such as shared understanding, a common language, a shared domain of knowledge, and interaction quality between business and IT [36].

\subsection{IO e-Service Delivery}

The IO e-service delivery and business process changes should be part of analysis and design. There is a need to re-organize back-office processes in order to provide eservices of high quality and improve IO coordination and integration [29]. Millard et al. [28] show that interoperability is easiest achieved between agencies with a tradition of cooperation. Thus, a long-term collaborative relationship is viewed as a source of success. The management challenge increases relative to the scope and number of stakeholders, for example services at tourism destinations including local people, visitors, private enterprises, the public sector, and intermediaries [33]. Thus, end-toend processes are hard to overview from the user perspective and difficult to grasp with an "ecosystem view" of e-services. With social media as part of the delivery, it is difficult to predict where the e-service starts and who are involved in the delivery. Hence, the scope and processes might involve many internal and external actors and are more or less complex to survey, manage and orchestrate. Furthermore, employees' willingness to recommend e-services in their daily business as well as citizens' adoption and use are prerequisites for benefits to arise [39].

In delivery, the essential factor is supporting users with information content to find, understand and use the e-service [6] through website layers [7], and web-related technologies [33]. In addition, skills related to intrapersonal and interpersonal communication [33], business process management and the ability to communicate e-services in terms of information content management [6] are crucial. Thus, the ability to achieve local business and IT alignments are a multiple task across departments involved in the e-service delivery. Government officials, who both provide services and benefit from them in their public exercise of duty, are to be viewed as co-producers of service delivery together with external users (citizens, businesses, non-profit organizations, and visitors). Hence, the IO public e-service development is both an internal IO business development across administrations and at the same time across organizations. Specifying requirements is therefore a complex task, balancing demands on 
fully online services with many actors to agree on the business logic, legal, functional and technical solutions. Tseng and $\mathrm{Hu}$ [39] stress the fact that the social construct of e-services does matter, report on many e-service items not suitable for full online services, and point out that in addition, users are not demanding these services. Angelopoulos et al. [2], note that e-government efforts are contingent upon the willingness of the citizens to use e-services which, according to Nam [32] consist of service use, information use, and policy research (the latter is more engaged and concerned with society, neighbors and government). However, direct contact between citizens and the government is relatively rare according to Heeks [17] referring to Millard who presents an average of 1.6 times per year in Europe. Hence, development efforts measured on number of e-services, site visits and repeated use are not as adequate as measures on value in relation to both internal and external users.

\subsection{Challenges in IO public e-Service Development Phases}

Based on the literature review above, IO-related challenges in public e-service development phases are presented in a summary, see Table 1.

Table 1. Challenges (C) in IO public e-service development phases

Pre-conditions

- To get a functional partner match with private/ public/non-profit actors with multiple forces, rationales, goals, expectations, awareness, intention and grade of willingness (C1)

- To identify actors' behavior in relation to innovation, idea generation sources and development actions together with their possibilities for IT investment, resource allocation impact and market impact (C2)

- To identify in-house/in-team/external know-ledge, skills resources and environments by participation actors (C3)

- To staff a number of well-known and/or new actors with the same or different size of agencies, styles, cultures and collaboration competence (C4)

Design and Development

- To co-ordinate between stakeholders' own and common goals. Goals can exists on lo$\mathrm{cal} /$ regional/national/EU level and should be aligned and achieved in intra- and inter-business process design (C5)

- To align decisions, multiple skills and actions in and between levels of involved actors. To achieve win-win situations and mutual responsibility for the technical base, design, development, resilience and maintainability (C6)

- To work with more or less political support, visionary leaders, plans and regulatory/legal frameworks by involved actors (C7)

Delivery

- To co-ordinate stakeholders' intra- and inter-business processes and channels (C8)

- To communicate and co-ordinate employees' intra- and inter-organizational actions with different degree of automated service delivery and channel choices (C9)

To communicate multiple organizations' expectations on e-service quality with adequate measurements $(\mathrm{C} 10)$ 


\section{Findings: Challenges in IO Public e-Service Development}

The national e-service case aimed at developing an e-service for automated decisions of provisional driving license applications, i.e. to support case officers with cases that did not call for an extensive manual handling process). Benefits aimed for in the project were automatic handling of "unproblematic" applications, cost reduction, and faster decisions for citizens. By implementing the e-service, the agency should be able to save and reallocate resources to support more complex applications. An e-service like this also provided an opportunity to standardize the application handling processes across the nation and the 21 county administration boards. Prior to the project, the agencies had high expectations concerning the quality of data provided by citizens. The use of an e-service when applying for a provisional driving license made it possible to check the quality and the completeness of data automatically. Another advantage with the e-service was that the underlying IT system directs the citizen to the appropriate county administrative board - instead of having citizens wondering which board they belong to. The development project was hosted by Sweden's County Administrations but consisted of members from the Swedish Road Administration and several external IT consultancy firms delivering project services and IT applications.

In the regional e-service case the $\mathrm{IO}$ development participants include the county IT board, 16 local municipalities, one supplier and a national platform community. The objectives are to use standard e-services based on interpretative business rules without legal barriers in a shared technical infrastructure to reduce cost, increase service quality, increase access and easier contact for the citizens, save time and reallocate resources to more complex errands. The IO collaboration provides the ability to use financial resources better, to share competences and require, design and host eservices together. The "e-Office", made up of three employees lead the joint development and supports the municipalities with methods, testing, anchoring and training besides national and regional coordination. One e-service representative from each municipality is the local driver of development as well as coordinating the local service performance. Each local administrative unit is responsible for requirements and service delivery; both issues are difficult to coordinate without a defined role. Hence, the ability, expectations and willingness of the representatives vary, as well as skills and motivation. One challenge is to empower administrations to accept their e-service ownership responsibility. The e-Office acts as a "broker" in the political environment with a pedagogic challenge to align politics, business, and IT in order to explain needs versus technical drivers. Decisions on e-government are made on national and regional level and turn into services on the local level were they are delivered and used. The local municipality administrations are responsible for the e-service and further improvements. However, even smaller changes might be difficult to make as a new version activates the implementation process with a great deal of work for involved parties. Thus, improvements depend on the supplier and the customers' network where development efforts on functionality are shared in a national, regional and local winwin. 
In order to structure the IO challenges identified in literature and the empirical cases we use key lessons presented by Axelsson and Melin [3], see Table 2. The abbreviations $\mathrm{N}$ (the national e-service case) and $\mathrm{R}$ (the regional e-service case) are used.

Table 2. IO challenges in previous research and in the national and the regional case

\begin{tabular}{|c|c|c|}
\hline Six key lessons & IO challenges in literature & IO challenges in cases \\
\hline $\begin{array}{l}\text { 1) An e-government project } \\
\text { should be initiated based on } \\
\text { someone's explicit need for } \\
\text { the e-service - there should } \\
\text { be a problem that the e- } \\
\text { service would solve or a } \\
\text { situation to facilitate }\end{array}$ & $\begin{array}{l}\text { To get a functional partner } \\
\text { match }(\mathrm{C} 1) \\
\text { To identify actors' behavior } \\
\text { in relation to innovation } \\
\text { (C2) } \\
\text { To get political and man- } \\
\text { agement support (C7) }\end{array}$ & $\begin{array}{l}\text { To decide for develop with- } \\
\text { out knowing if the citizens } \\
\text { ask for the e-service (N1) } \\
\text { To identify a local need } \\
\text { when representatives are } \\
\text { lacking motivation of e- } \\
\text { service initiatives (R1) }\end{array}$ \\
\hline $\begin{array}{l}\text { 2) E-service development } \\
\text { projects should be based on a } \\
\text { thorough understanding of } \\
\text { citizens' needs and require- } \\
\text { ments }\end{array}$ & $\begin{array}{l}\text { To co-ordinate goals and } \\
\text { drivers between levels: } \\
\text { local, regional, national, EU } \\
\text { (C5) }\end{array}$ & $\begin{array}{l}\text { To align knowledge be- } \\
\text { tween levels and organiza- } \\
\text { tions without someone } \\
\text { responsible (N2) } \\
\text { To align needs and objec- } \\
\text { tives between levels in } \\
\text { value evaluation and priori- } \\
\text { tization (R2) }\end{array}$ \\
\hline $\begin{array}{l}\text { 3) The security and identifica- } \\
\text { tion solutions chosen should } \\
\text { be carefully examined in } \\
\text { relation to the specific target } \\
\text { groups of the e-service }\end{array}$ & und in the literature & $\begin{array}{l}\text { To choose an identification } \\
\text { solution (eID) that was very } \\
\text { difficult to get access to for } \\
\text { a main target group of the e- } \\
\text { service (N3) }\end{array}$ \\
\hline $\begin{array}{l}\text { 4) The e-service in itself } \\
\text { cannot be the only scope of } \\
\text { the project; the complexity of } \\
\text { internal and IO process } \\
\text { changes and the general con- } \\
\text { text must also be understood }\end{array}$ & $\begin{array}{l}\text { To co-ordinate stakehold- } \\
\text { ers' intra- and inter- } \\
\text { business processes }(\mathrm{C} 8) \\
\text { To achieve win-win and } \\
\text { mutual responsibility }(\mathrm{C} 6) \\
\text { To communicate stakehold- } \\
\text { ers' expectations in relation } \\
\text { to quality and adequate } \\
\text { measurements }(\mathrm{C} 10)\end{array}$ & $\begin{array}{l}\text { To perform IO business } \\
\text { process analysis with stake- } \\
\text { holders who can motivate } \\
\text { and realize business chang- } \\
\text { es and design of service and } \\
\text { support without ownership } \\
\text { of e-services (R3) }\end{array}$ \\
\hline $\begin{array}{l}\text { 5) An e-government develop- } \\
\text { ment project should be } \\
\text { properly planned and staffed } \\
\text { with persons with an appro- } \\
\text { priate competence }\end{array}$ & $\begin{array}{l}\text { To staff a number of actors; } \\
\text { size of agencies, styles, } \\
\text { cultures and collaboration } \\
\text { competence (C4) } \\
\text { To identify knowledge, } \\
\text { skills resources and envi- } \\
\text { ronments (C3) }\end{array}$ & $\begin{array}{l}\text { To ensure in-house devel- } \\
\text { opment competence lead to } \\
\text { a high dependence on con- } \\
\text { sultants (N4) To ensure a } \\
\text { process to co-ordinate the } \\
\text { IO development when expe- } \\
\text { rience was lacking (R4) }\end{array}$ \\
\hline $\begin{array}{l}\text { 6) Analysis of legal pre- } \\
\text { conditions for the e-service } \\
\text { should be done in the very } \\
\text { beginning }\end{array}$ & $\begin{array}{l}\text { To communicate and co- } \\
\text { ordinate different degrees of } \\
\text { automated service delivery } \\
\text { and channel choices (C9) }\end{array}$ & $\begin{array}{l}\text { To highlight regulations and } \\
\text { sections of the law when } \\
\text { identifying a potential ser- } \\
\text { vice to develop (N5 + R5) }\end{array}$ \\
\hline
\end{tabular}

According to the analysis in Table 2 an explicit need for the e-service is in an IO context based on participating partners' local levels (employees and external users) as well as the regional and national levels in terms of re-use solutions in a broader sense. 
Thus, there is a challenge to motivate and support local e-service representatives to take the lead and identify local needs as well as to co-ordinate needs on a region$\mathrm{al} /$ national level. Hence, the partner match aspect is crucial in planning and staffing private/public/non-profit actors and their representatives. In addition, political and management support is needed as well as methodological support for instance for identifying and prioritizing whose needs should be served.

Basing the development of an e-service on a thorough understanding of citizens' needs and requirements is an ideal situation. However, to get users to express requirements for new services/solutions, in order to get an adequate user representation, is difficult. One way to identify requirements is to map the IO business processes with the external user in focus as well as the service impact on and demands for internal and external changes. However, before a business process mapping, the potential eservices to be developed need to be identified and prioritized. In this part of the work practice, regulations must be interpreted in the same way in order to develop an eservice to be used at a regional or national level.

The process design of the e-service delivery offers a possibility to co-ordinate resources and actions to achieve win-win and decide on mutual responsibilities. In addition, the expectations of organizations in relation to e-service quality can be based on measurements, such as the number of cases to handle, time-savings, channel choices and quality in performance instead of less adequate measurements like numbers of eservices, site visits and repeated use.

\section{Conclusions}

The purpose of this paper has been to further elaborate on challenges in IO public eservice development with the aim of generating lessons for such development. Our conclusions are based on the key lessons formulated by Axelsson and Melin [3], but put in an explicit IO focus in this paper, also revisiting the cases in the section above, and the analysis in the previous section. The major contribution is to further develop the reported lessons through adding an explicit IO dimension of e-service development. Eight emerging lessons learned (L), below, are related to different phases in the development process:

\section{Pre-conditions for Public IO e-Service Development}

L1: E-service initiatives should be based on rationales connected to objectives at different levels (EU, national, regional, local) and the possibility to promote development corresponding to environment. L2: E-service design, development and delivery should handle the political, public and personal character of the e-service and its internal and external use based on a common decision between multiple stakeholders. 


\section{Design and Development of IO Public e-Services}

L3: E-service development should be initiated by someone's explicit need for the eservice (a problem to solve or a situation to facilitate) and based on expected (and evaluated) user value. L4: E-service development should be properly planned and staffed with persons with an appropriate partner match, competence, ability and responsibility defined with a mandate to act upon. L5: E-service design should be based on early-identified legal restrictions and the possibility to reach common regulations for e-service delivery provided by the involved stakeholders, that is service providers and users.

\section{Delivery of IO Public e-Services}

L6: E-service delivery should be based on IO business process analysis and design.

L7: E-service security and identification solutions chosen should be carefully examined based on user types. L8: E-services should be delivered in relevant and multiple channel choices according to users' needs.

\subsection{Implications and Future Research}

In this paper eight emerging lessons corresponding to different phases in the development process were presented. We focused on the IO dimension of the e-service development process, but do not claim that all aspects of the challenges and emerging lessons are exclusive for the IO context. Actually, the case is rather the opposite; several of the challenges and lessons have been reported in previous research and practice. However, we would like to highlight the level of complexity with multiple stakeholders (for instance regarding objectives), challenges related to processes and staffing across organizational borders, and the choice of joint channels as particularly important aspects of IO e-service development. The implications for both practice and research are that the challenges that have to be handled at various stages need to be defined, and frameworks and methods developed in order to support the development practice. Our findings emphasize the importance of pre-conditions as a part of IO public e-service development in order to support alignment between strategic and business development at multiple levels with many issues to be handled from partner match to methodological support in the context of joint development. The IO dimension of multiple actors and levels is important to enable the design, development and delivery of public e-services.

One limitation in our work is the choice of two cases within the same national context. Future research can extend the national domain (for instance to include several countries within the European Union). Another possible avenue for further research is to use further analytically refine the lessons above, elaborate more on the design and development process as a point of departure for action and contextualization, and doing so as a means of validation and further improvement. 


\section{References}

1. Alter, C., Hage, J.: Organizations working together, Sage, Newbury Park, Calif (1993)

2. Angelopoulos, S., Kitsios, F., Papadopoulos, T.: New service development in egovernment: identifying critical success factors, Transforming Government: People Process and Policy, vol. 4 (1), pp. 95-118, (2010)

3. Axelsson, K., Melin, U.: Six Key Lessons for E-Government Projects, In: Proceedings of EGOV, pp. 93-103, (2009)

4. Axelsson, K., Melin, U.: An inter-organisational perspective on challenges in onestop government, International Journal of Electronic Governance, vol. 1(3), pp. 296-314, (2008)

5. Axelsson, K., Melin, U., Lindgren, I.: Public e-services for agency efficiency and citizen benefit - Findings from a stakeholder centered analysis, Government Information Quarterly, vol. 30(1), pp. 10-22, (2013)

6. Christiansson, M-T.: Improving Citizens' Ability to Find, Understand and Use eServices: Communicating the Social Interaction Dimension, Systems, Signs \& Actions, vol. 7(2), pp. 177-204, (2013)

7. Christiansson, M-T., Wik, M.: Testing Communicability in Public e-Services: Process and Outcomes, In: Proceedings of EGOV and Electronic Participation, IOS Press, DOI: 10.3233/978-1-61499-429-9-244, pp. 244-253, (2014)

8. Chun, S.A., Luna-Reyes, L.F., Sandoval-Almazá n, R.: Guest Editorial: Collaborative e- government, Transforming Government: People Process and Policy, vol. 6(1), pp. 5-12, (2012)

9. Dawes, S., Eglene, O.: New models of collaboration for delivering e-government services: A dynamic model drawn from multi-national research, Center for Technology in Government, pp. 1-17, (2008)

10. Dawes, S.: Governance in the digital age: A research and action framework for an uncertain future, Government Information Quarterly, vol. 26(2), pp. 257-264, (2009)

11. Gibson, J. J.: The Theory of Affordances, In: Shaw, R. and Bransford, J. (Eds.). Perceiving, Acting, and Knowing: Toward an Ecological Psychology, Lawrence Erlbaum, Hillsdale, NJ, pp. 67-82, (1977)

12. Government Offices of Sweden.: The Swedish model of government administration - three levels, (2014), http://www.government.se/sb/d/2858

13. Government Offices of Sweden.: Ministry of Enterprise, Energy and Communications, Swedish Government strategy on a digital collaborative public administration, (2012), http://www.regeringen.se/sb/d/15700/a/206004

14. Government Offices of Sweden.: Ministry of Enterprise, Energy and Communications, ICT for Everyone - A Digital Agenda for Sweden, N2011.19, (2011), http://www.government.se/sb/d/2025/a/181914

15. Guha, J., Chakrabarti, B.: Making e-government work: Adopting the network approach, Government Information Quarterly, 31(2), pp. 327-336, (2014) 
16. Hassan, H.S., Shehab, E., Peppard, J.: Recent advances in e-service in the public sector: state-of-the-art and future trends, Business Process Management Journal, vol. 17(3), pp. 526-545, (2011)

17. Heeks, R.: Benchmarking E-government: Improving the National and International Measurement, Evaluation and Comparison of E-government, In: Irani, Z. and Love, P. (Eds.) Evaluating Information Systems: Public and Private Sector, Elsevier Ltd, (2008)

18. Heeks, R.: Implementing and Managing eGovernment - An international text, SAGE, London, (2006)

19. Iskender, G., Özkan, S.: E-government transformation success: An assessment methodology and the preliminary results, Transforming Government: People, Process and Policy, vol. 7(3), pp. 364-392, (2013)

20. Jupp, V.: Realizing the vision of e-government. In Curtin, G.C., Sommer, M.H. and Vis-Sommer, V. (Eds), The World of E-government, Haworth Press, New York, NY, pp. 129-145, (2003)

21. Klievink, B., Janssen, M.: Challenges in Developing Public-private Business Models, European Journal of ePractice, (18), (2012) http://www.epracticejournal.eu

22. Lindgren, I.: Public e-service stakeholders - A study on who matters for public eservice development and implementation, $\mathrm{PhD}$ thesis No. 580, Linköping University, (2013)

23. Lindgren, I., Jansson, G.: Electronic services in the public sector: A conceptual framework, Government Information Quarterly, vol. 30, pp. 163-172, (2013)

24. Luftman, J., Rajkumark, K.: An update on business/alignment: a line has been drawn. MIS Quarterly Executive, vol. 6(3), pp. 165-177, (2007)

25. Madsen, C. Ø., Bull Berger, J., Phythian, M.: The Development in Leading eGovernment Articles 2001-2010: Definitions, Perspectives, Scope, Research Philosophies, Methods and Recommendations: An Update of Heeks and Bailur, In: Proceedings of EGOV, pp. 17-34, (2014)

26. Magnusson, M., Christiansson, M-T.: Using Goal Modelling to Evaluate Goals for e- Service Development in Government, ECIME, pp. 312-320, (2011)

27. Melin, U., Axelsson, K.: Managing e-service development - comparing two egovernment case studies, Transforming Government: People, Process and Policy, vol. 3(3), pp. 248-270, (2009)

28. Millard, J., Iversen, J. S., Kubicek, H., Westholm, H., Cimander, R.: Reorganisation of Government Back-offices for Better Electronic Public Services - European Good Practices, Main report, European Commission, Brussels, (2004)

29. Millard, J.: Are you being served? Transforming e-government through service personalisation, International Journal of Electronic Government Research, vol. 7(4), pp. 1-18, (2011)

30. Myers, M.D.: Qualitative Research in Business \& Management, SAGE Publications, London, (2009)

31. Myers, M. D., Klein, H. K.: A Set of Principles for Conducting Critical Research in Information Systems, MIS Quarterly, vol. 35(1), pp. 17-39, (2011)

32. Nam, T.: Determining the type of e-government use, Government Information Quarterly, vol. 31(2), pp. 211-220, (2014) 
33. Paskaleva-Shapira, K., Azorin, J., Chiabai, A.: Enhancing digital access to local cultural heritage through e-governance: innovations in theory and practice from Genoa, Italy, The European Journal of Social Sciences, vol. 21(4), pp. 389-405, (2008)

34. Rana, N. P., Dwivedi, Y. K., Williams, M. D.: Analysing challenges, barriers and CSF of egov adoption, Transforming Government: People, Process and Policy, vol. 7(2), pp. 177-198, (2013)

35. Sæbø, Ø., Rose, J., Skiftenes Flak, L.: The shape of eParticipation: Characterizing an emerging research area, Government Information Quarterly, vol. 25(3), pp. 400-428, (2008)

36. Schlosser, F.: Mastering the social IT/business alignment challenge, In: Proceedings of the 18th Americas Conference on Information Systems, AMCIS, AIS Electronic Library, United States, pp. 1843-1849, (2012)

37. SOU: Strategi för myndigheternas arbete med e-förvaltning, (2009), http://www.regeringen.se/sb/d/11456/a/133813 (in Swedish)

38. Susman, G.: Action Research: A Sociotechnical Perspective, In: Beyond Method: Strategies for Social Research, Morgan, G. (Ed.), Sage Publications, Newbury Park, pp. 95-113, (1983)

39. Tseng, K-C., Hu, L-T.: To cross or not to cross the boundaries? A reflection on electronic public service integration, In: Chen, Y-C. and Chu, P-Y. (Eds.). Electronic Governance and Cross-Boundary Collaboration: Innovations and Advancing Tools, IGI Global, pp. 2-22, (2012)

40. Tsou, H. T.: Collaboration competency and partner match for e-service product innovation through knowledge integration mechanisms, Journal of Service Management, vol. 23(5), pp. 640-663, (2012)

41. Van de Ven, A. H.: Engaged scholarship: a guide for organizational and social research, Oxford University Press, (2007)

42. Walsham, G.: Doing Interpretive Research, European Journal of Information Systems, vol. 15(3), pp. 320-330, (2006)

43. E-delegation.: Vägledning för behovsdriven utveckling, (2012), http://www.behovsdrivenutveckling.se, (in Swedish)

44. European Commission.: Digital Agenda for Europe: A Europe 2020 Initiative, Scoreboard 2014 - Developments in eGovernment in the EU 2014, (2014), https:/ec.europa.eu/digital-agenda/en/news/scoreboard-2014-developmentsegovernment-eu-2014 